\title{
INOVASI PEMBELAJARAN (INKLUSI) PENDIDIKAN JASMANI BERBASIS PERMAINAN KECIL UNTUK MAHASISWA BERKEBUTUHAN KHUSUS
}

\author{
Hayudi ${ }^{1}$, Mursalim $^{2}$ \\ 1,2 Universitas Pendidikan Muhammadiyah Sorong \\ E-mail: hayudibuton86@gmail.com¹, mursalim47@gmail.com² \\ DOI: https://doi.org/10.36526/kejaora.v5i2.929
}

\begin{abstract}
ABSTRAK
Program pembelajaran belum memasukkan mata kuliah pendidikan inklusif sesuai amanah UU No. 8 tahun 2016, yaitu mahasiswa yang berkebutuhan khusus masih diikutkan dalam kelas yang sama dengan mahasiswa umum (tidak memiliki hambatan belajar) sehingga ini menjadi kendala dan tantangan belajar bagi mahasiswa berkebutuhan khusus. Proses kegiatan belajar mengajar berlangsung dalam satu arah dimana dosen cenderung dominan (aktif) sementara mahasiswa menunggu (pasif) dan belum mengakomodir mahasiswa yang berkebutuhan khusus. Sarana dan prasarana yang digunakan sangat terbatas sehingga berdampak pada keaktifan mahasiswa untuk mempraktekkan atau melakukan suatu gerakan juga ikut terkendala. Penelitian ini merupakan penelitian pengembangan (Research and Development). Prosedur penelitian menggunakan: (1) Research and Information Collection, (2) Planning, (3) Develop Preliminary form of product, (4), validasi desain, (5) Main Product revision, (6) Main filed testing, (7) Operational product revision, (8) Operational field testing, (9) Final Product revision. Simpulan dalam penelitian ini adalah menghasilkan produk berupa model modifikasi permainan kecil yang terdiri atas: 1) permainan bagian tubuh (kerucut), 2) permainan tepuk ambil, 3) permainan bola gotong. Model-model tersebut telah dinilai oleh expert judgment dan mendapatkan kesimpulan bahwa model tersebut dinyatakan valid dan layak untuk digunakan.
\end{abstract}

Kata Kunci: Pendidikan Jasmani, Permainan Kecil, Mahasiswa Berkebutuhan Khusus

\section{PENDAHULUAN}

Kehidupan menjelang abad ke-21 menuntut berbagai keterampilan yang harus dimiliki oleh setiap individu, pemenuhan atas berbagai keterampilan itu sejalan dengan proses pendidikan yang harus dilalui oleh setiap individu. Sehingga pendidikan diharapkan mampu mempersiapkan peserta didik untuk menjawab sesuai tantangan zamannya. Pendidikan yang diharapkan adalah pendidikan yang sesuai dengan empat pilar pembelajaran yaitu learning to know, learning to do, learning to be, dan learning to live together. Empat pilar tersebut hendaknya menjiwai setiap proses kegiatan belajar mengajar. Ini sesuai dengan pernyataan bahwa pembelajaran abad ke-21 memiliki prinsip pokok bahwa pembelajaran harus berpusat pada siswa, bersifat kolaboratif, kontekstual, dan terintegrasi dengan masyarakat (Siti Zubaidah, 2016)
Tujuan pendidikan untuk mewujudkan pertumbuhan kepribadian manusia secara seimbang dan menyeluruh, juga mengembangkan manusia di dalam segala aspek, baik aspek fisik, intelektual, pengembangan diri dan spiritual. Hal ini juga ditegaskan dalam Undang-Undang Sistem Pendidikan Nasional No. 20 tahun 2003 bahwa setiap warga negara mempunyai hak yang sama untuk memperoleh pendidikan yang bermutu dan berhak mendapat kesempatan meningkatkan pendidikan sepanjang hayat, artinya semua warga yang berada di Negara Kesatuan Republik Indonesia dijamin oleh negara untuk mendapatkan pelayanan pendidikan yang bermutu dan dapat dinikmati oleh semua penduduk Indonesia tak terkecuali kepada mahasiswa yang berkebutuhan khusus (ABK). 
Jurnal Kejaora: Jurnal Kesehatan Jasmani dan Olah Raga

ISSN: 2541-5042 (Online)

ISSN: 2503-2976 (Print)

Volume 5 Nomor 2, Edisi November 2020

Undang-Undang Nomor 8 Tahun 2016 Tentang Penyandang Disabilitas menyatakan penyandang disabilitas berhak mendapatkan pendidikan yang bermutu di semua jenis, jalur dan jenjang pendidikan secara inklusif dan khusus. Kemudian pasal 40 ayat 1 pemerintah dan pemerintah daerah wajib menyelenggarakan dan atau memfasilitasi pendidikan untuk penyandang disabilitas disetiap jalur, jenis, dan jenjang pendidikan sesuai dengan kewenangannya.

Permendikti No 46 Tahun 2017 Tentang Pendidikan Khusus dan Layanan Khusus di Perguruan Tinggi, mengatur mengenai hak dan kewajiban mahasiswa berkebutuhan khusus, hak dan kewajiban perguruan tinggi, serta tata kelola layanan akademik, administrasi dan kemahasiswaan bagi mahasiswa berkebutuhan khusus di Perguruan Tinggi (PT).

Sementara itu UU No. 12 tahun 2012 Tentang Pendidikan Tinggi pasal 32 ayat (1) menyatakan bahwa layanan pendidikan bagi penyandang disabilitas di perguruan tinggi dapat dilakukan dalam bentuk pendidikan khusus dan pendidikan layanan khusus. Menurut permenristekdikti No. 46 tahun 2017 tentang pendidikan khusus dan pendidikan layanan khusus di perguruan tinggi pada pasal 8 ayat (1) menyatakan bahwa perguruan tinggi memfasilitasi pembelajaran dan penilaian sesuai dengan kebutuhan mahasiswa berkebutuhan khusus tanpa mengurangi mutu hasil pembelajaran, dan pada ayat (2) menyatakan bahwa pembelajaran sebagaimana dimaksud pada ayat (1) dapat dilakukan dalam bentuk penyesuaian: a. Materi; b. Alat/media; c. Proses pembelajaran; dan/ataud. Penilaian.

Fakta di lapangan menunjukkan Universitas Pendidikan menerima mahasiswa berkebutuhan khusus yang terdaftar di program studi Pendidikan Jasmani (Penjas) dan Pendidikan Guru Sekolah Dasar (PGSD), dengan kategori masing-masing memiliki hambatan penglihatan (tunanetra) dan hambatan pendengaran (tunarungu).

Khusus untuk mahasiswa program studi PGSD ada satu mata kuliah yang harus di program yaitu mata kuliah Pendidikan

Jasmani Kesehatan dan Rekreasi (PJKR) dengn beban SKS sebanyak 3 (tiga) SKS. Sehingga mahasiswa diwajibkan untuk mengambil mata kuliah tersebut. Kesiapan kampus UNIMUDA untuk memenuhi Permenristek Dikti Nomor 46 tahun 2017 Tentang Pendidikan Khusus dan Layanan Khusus terlihat belum maksimal, dimana penyelenggaraan program pembelajaran belum memasukkan mata kuliah pendidikan inklusif sesuai amanah UU No. 8 tahun 2016, yaitu mahasiswa yang berkebutuhan khusus masih diikutkan dalam kelas yang sama dengan mahasiswa umum (tidak memiliki hambatan belajar) sehingga ini menjadi kendala dan tantangan belajar bagi mahasiswa berkebutuhan khusus.

Hasil observasi yang dilakukan oleh peneliti pada tanggal 7 s/d 14 Juli 2019 masih ditemukan bahwa model pembelajaran yang digunakan masih menggunakan metode ceramah yang mengarah pada kemampuan kognitif. Proses kegiatan belajar mengajar berlangsung dalam satu arah dimana dosen cenderung dominan (aktif) sementara mahasiswa menunggu (pasif) dan belum mengakomodasikan mahasiswa yang berkebutuhan khusus. Sarana dan prasarana yang digunakan sangat terbatas sehingga berdampak pada keaktifan mahasiswa untuk mempraktekkan atau melakukan suatu gerakan juga ikut terkendala.

Peneliti memilih inovasi pembelajaran pendidikan jasmani berbasis permainan kecil karena permainan yang dikembangkan merupakan salah satu permainan tradisional masyarakat Papua. Pengembangan permainan kecil ini sebagai upaya mewujudkan pelestarian kebudayaan lokal. Hasil inovasi permainan kecil diharapkan mahasiswa yang berkebutuhan khusus semakin termotivasi dan memiliki kepercayaan diri untuk melakukan aktivitas fisik, peningkatan kebugaran fisik serta dampak yang lebih jauh adalah aktif seumur hidup (aktive for life). Peralatan yang digunakan dalam inovasi permainan kecil menggunakan peralatan yang murah dan sederhana yang bisa didapatkan di lingkungan sekitar kampus, sehingga tidak membutuhkan dana untuk mendapatkannya. 
Oleh sebab itu dosen dituntut untuk mengembangkan inovasi dan kreativitas dalam pembelajaran agar mahasiswa dapat memenuhi target pembelajaran yang ditetapkan oleh dosen. Adapun bentuk inovasi dan kreativitas pembelajaran yang dikembangkan adalah pengembangan permainan kecil dalam pembelajaran inklusi pendidikan jasmani.

Pendidikan jasmani merupakan bagian integral dari pendidikan pada umumnya, pendidikan jasmani dalam pelaksanaannya bukan hanya bertumpu pada aktifitas fisik tetapi berdampak sangat kuat terhadap perkembangan dan keberfungsian nilai-nilai sosial dalam olahraga. Melalui pendidikan jasmani yang diarahkan dengan baik, mahasiswa akan mengembangkan keterampilan yang berguna bagi aktivitas fisik dengan tujuan pengembangan hidup sehat, perkembangan kehidupan sosial bagi mahasiswa, dan tidak kalah pentingnya yaitu peningkatan kebugaran jasmani. Hal ini sesuai dengan pernyataan yang disampaikan oleh Bangun bahwa pendidikan jasmani adalah pendidikan yang memanfaatkan aktivitas jasmani yang direncmahasiswaan secara sistematik bertujuan untuk mengembangkan dan meningkatkan individu secara organik, neuromuskular, perseptual, kognitif, dan emosional dalam kerangka sistem pendidikan nasional (Bangun, 2016)

Permainan dan gerak adalah dua hal yang tidak bisa dipisahkan. Permainan akan terjadi jika ada perpindahan tempat melalui gerak. Dengan adanya permainan akan mendorong mahasiswa untuk selalu bergerak, hasil adanya gerakan membantu meningkatkan kecerdasan kinestetik mahasiswa. Bentuk permainan yang dilaksmahasiswaan hendaknya berdasarkan usia dan dalam jangkauan motorik mahasiswa sehingga mahasiswa lebih aman dalam bermain.

Permainan kecil merupakan suatu bentuk permainan yang tidak mempunyai peraturan tertentu, baik mengenai peraturan permainannya, alatnya, ukuran lapangan, maupun waktu pelaksanaaannya. Bentuk permainan kecil yang sering digunakan terdiri atas 2 yaitu permainan tanpa alat dan permainan dengan alat. Permainan kecil juga sering disebut dengan permainan tradisional yang berakar dari budaya suatu bangsa (Kurniawan \& Hayudi, 2018). Budaya bangsa Indonesia yang beragam memiliki potensi besar untuk pengembangan sumber daya manusia. Permainan kecil merupakan bentuk permainan yang bermanfaat bagi pertumbuhan dan perkembangan fisik mahasiswa serta berperan penting dalam penanaman nilai, baik sikap dan keterampilan.

Oleh karena itu, pendidikan jasmani dalam berupaya agar semua kebutuhan mahasiswa akan gerak dapat terpenuhi dan dapat meningkatkan potensi yang dimilikinya secara optimal. Pada kenyataannya tidak semua ABK mendapatkan layanan pendidikan jasmani sesuai dengan kebutuhan atau hambatan yang dimilikinya, Melalui pendidikan jasmani adaptif kita bisa memuliakan mahasiswa berkebutuhan khusus sesuai dengan keterbatasan dan tingkat kemampuan (Hakim, 2017).

Berdasarkan permasalahan tersebut, peneliti tertarik untuk membuat model pembelajaran penjas melalui pendekatan modifikasi permainan kecil. Sehingga para mahasiswa dapat bergerak secara aktif, efektif, dan efisien, dengan menggunakan peralatan sederhana yang dapat dimodifikasi sesuai yang dibutuhkan.

\section{Hakikat Permainan Kecil Untuk Mahasiswa Berkebutuhan Khusus}

Klasifikasi mahasiswa tunanetra ada enam: 1. Mahasiswa tunanetra total bawaan atau yang diderita sebelum usia 5 tahun. 2 . Mahasiswa tunanetra total yang diderita setelah usia 5 tahun. 3. Mahasiswa tunanetra sebagian karena faktor pembawaan. 4 . Mahasiswa tunanetra sebagian akibat sesuatu yang didapat kemudian. 5 . Mahasiswa dapat melihat sebagian karena faktor bawaan. 6 . Mahasiswa dapat melihat sebagian akibat tertentu yang didapat kemudian (Abdullah, 2012). Dalam konteks ini klasifikasi mahasiswa tunanetra yang dijadikan sebgai obyek penelitian adalah adalah mahasiswa dalam kategori mahasiswa dapat melihat sebagian karena faktor bawaan. 
Jurnal Kejaora: Jurnal Kesehatan Jasmani dan Olah Raga

ISSN: 2541-5042 (Online)

ISSN: 2503-2976 (Print)

Volume 5 Nomor 2, Edisi November 2020

Penalaran merupakan suatu proses berpikir dalam menarik sesuatu kesimpulan yang berupa pengetahuan si mahasiswa (tuna netra) sehingga wujudnya bisa menjadi sebuah gerakan tari yang diinginkan atau diajarkan oleh sang pelatih (Muharomah, 2016).

Proses kegiatan pembelajaran langsung mempunyai pengaruh yang cukup signifikan yaitu dapat meningkatkan kemampuan orientasi dan mobilitas pada mahasiswa tunanetra untuk menjadi lebih baik lagi (Ratnasari, 2015). Pola interaksi guru dan mahasiswa tunanetra dalam pembelajaran berlangsung dalam interaksi dua arah (Widyastuti, 2016). Sehingga dapat disimpulkan bahwa kegiatan pembelajaran yang baik untuk mahasiswa tunanetra adalah model kegiatan pembelajaran langsung dengan pola interaksi dua arah yaitu antara mahasiswa dengan dosen.

Peran dukungan sosial dalam pembentukan self esteem remaja tunanetra di sekolah/kampus khusus sangat dibutuhkan. Dukungan sosial yang dimaksud adalah dukungan emosional, dukungan penghargaan, dukungan instrumental, dukungan informasi, dan dukungan jaringan sosial. Sedangkan self esteem yang dimaksud adalah penilaian pribadi terhadap suatu perasaan berharga yang diekspresikan ke dalam sikap-sikap yang dipegang oleh individu (Khoiroh \& Paramita, 2014). Sehingga dapat disimpulkan bahwa ABK (tunanetra) butuh dukungan penuh dari lingkungan tempat tinggal terutama keluarga terdekat. Dalam konteks pendidikan, dukungan yang diberikan berupa model pembelajaran yang menyenangkan, jika mereka terlibat dalam aktivitas yang menghibur, ini akan membantu mereka dalam hal menjaga mereka tetap fokus dan konsentrasi, membantu membentuk perilaku positif terhadap aktivitas fisik, membuat mereka lebih aktif serta memiliki kepercayaan diri untuk meningkatkan kemampuan belajarnya.

Inovasi sebagai suatu ide, gagasan, praktik atau obyek/benda yang disadari dan diterima sebagai suatu hal yang baru oleh seseorang atau kelompok untuk diadopsi. Oleh sebab itu, inovasi pada dasarnya

merupakan pemikiran cemerlang yang bercirikan hal baru ataupun berupa praktikpraktik tertentu ataupun berupa produk dari suatu hasil olah-pikir dan olah-teknologi yang diterapkan melalui tahapan tertentu.

Inovasi pembelajaran berdampak positif dalam proses belajar mengajar terutama untuk mengarahkan perhatian peserta didik sehingga menimbulkan motivasi untuk belajar dan materi yang diajarkan akan lebih jelas, cepat dipahami sehingga dapat menigkatkan prestasi siswa (April, 2015). Dari pendapat diatas dapat disimpulkan bahwa inovasi pembelajaran sangat perlu untuk dilakukan terutama dalam meningkatkan konsentrasi peserta didik, melalui inovasi pembelajaran yang baik akan berdampak pada prestasi akademik maupun non akademik juga meningkat.

Pendidikan jasmani memiliki kontribusi besar pada proses perkembangan peserta didik, dimana dalam pelaksanaannya menjadikan aktivitas jasmani sebagai alat untuk mencapai tujuan pendidikan (Utama, 2011). Senada dengan pernyataan Abduljabar bahwa pendidikan jasmani menekankan pada kebugaran jasmani, penguasaan keterampilan, pengetahuan, dan perkembangan sosial (Abduljabar, 2011).

Salah satu proses pembelajaran penjas untuk $A B K$ tunanetra haruslah dirancang sesuai dengan kebutuhan, kemampuan dan karakteristik peserta didik. Inovasi pembelajaran yang dilakukan pada kegiatan ini adalah pembelajaran dalam permainan yang menyenangkan, penting bagi mereka untuk mengembangkan keterampilannya dalam pendidikan jasmani, sehingga mengembangkan hubungannya dengan teman-teman sebaya. Ini akan meningkatkan rasa percaya diri dan keyakinan diri terutama peningkatan dalam bidang olahraga. Sesuai dengan pernyataan bahwa Pendidikan Jasmani selain terbukti memberi keuntungan terhadap dimensi fisik tetapi juga diyakini memberi keuntungan terhadap pengembangan dimensi afektif, sosial dan kognitif (Widiyatmoko, 2017). 


\section{Tujuan Pembelajaran Permainan Kecil Bagi Mahasiswa Berkebutuhan Khusus}

Pendidikan inklusif memiliki tujuan untuk mengurangi sikap diskriminatif pada mahasiswa berkebutuhan khusus. Peranan seorang pembimbing khusus sangat diperlukan dalam mengoptimalkan perkembangan mahasiswa secara akademik maupun nonakademik. Pembimbing khusus bukan semata-mata mendampingi mahasiswa dalam belajar melainkan juga memberikan pelayanan yang sesuai dengan kebutuhannya (Wardah, 2019). Pendidikan inklusi bertujuan untuk mengakomodasi semua mahasiswa tanpa memandang kondisi fisik, intelektual, sosial emosional, linguistik atau kondisi lainnya (Setianingsih, 2018).

Secara umum tujuan permainan kecil bagi mahasiswa berkebutuhan khusus adalah untuk membantu agar mahasiswa dapat berpartisipasi secara aktif dalam aktifitas peningkatan kemampuan kognitif, afektif dan psikomotorik. Sedangkan secara khusus pembelajaran permainan kecil bagi mahasiswa berkebutuhan khusus adalah untuk membantu mahasiswa dalam peningkatan kebugaran jasmani, memiliki budaya hidup sehat, memiliki kepercayaan diri untuk berinteraksi dengan lingkungan dan meningkatkan kemampuan belajar.

\section{Manfaat Pembelajaran Permainan Kecil Bagi Mahasiswa Berkebutuhan khusus}

Menurut Jusuf Blegur dan M. Rambu P. Wasak Manfaat pembelajaran permainan kecil bagi mahasiswa adalah sebagai berikut : (1) Sarana menyalurkan energi, (2) Melatih dan meningkatkan kebugaran jasmani, (3) Melatih dan mengembangkan motor educability, (4) Sarana pengembangan olahraga prestasi, (5) Melatih dan meningkatkan interaksi sosial-emosional, (6) Melatih dan meningkatkan disiplin dan pengendalian diri, (7) Melatih dan meningkatkan kepercayaan diri, (8) Melatih dan meningkatkan kepemimpinan yang transformatif, (9) Melatih dan mengembangkan keterampilan berpikir kritis, (10) Melatih dan meningkatkan keterampilan berpikir kreatif (Blegur J \& Rambu M, 2017).
Tahapan Pembelajaran Permainan Kecil

Menurut Auxer, Pyfer, dan Huetting (2010), dalam perencanaan pembelajaran harus memahami secara jelas tahapan fungsi perkembangan motorik dalam berbagai keterampilan motorik dalam berbagai keterampilan olahraga. Tahapan tersebut adalah tahap dasar pembangunan system saraf, tahap proses integrasi proses, tahap keterampilan fungsional, dan tahap keterampilan gerak.

1. Tahap dasar pembangunan system saraf

Tahap dasar pembangunan system saraf ini tergantung dari proses operasionalisasi system syaraf dalam menerima masukan atau system sensori syaraf. Sistem tersebut mencakup refleks primitive, system vestibular, penglihatan dan refractive,

pendengaran, perabaan, system kinestetik, dan refleks keseimbangan. Keseluruhan sistem tersebut merupakan komponen penting dalam gerakan yang berguna yang terdapat dalam central nerves system (CNS).

2. Tahap proses integrasi proses

Tahap integrasi proses dicapai setelah melalui tahap pertama tersebut di atas. Tahap pertama adalah tahap fungsi gerak, sedangkan tahap kedua adalah tahap berkaitan dengan kualitas gerak. Tahap integrasi proses mencakup persepsi motorik, seperti keseimbangan gerak, kesadaran tubuh, bayangan diri, dan kesadaran ruang. Persepsi motorik, kesegaran jasmani, dan kesegaran gerak (motor fitness). Persepsi motorik meliputi keseimbangan gerak, kesadaran tubuh, bayangan diri, dan kesadaran ruang. Kesegaran jasmani meliputi kekuatan otot, daya tahan otot, dan daya tahan kardiovaskuler. Kesegaran gerak meliputi kelincahan, power, kecepatan dan koordinasi

3. Tahap keterampilan fungsional

Tahap lanjut perkembangan gerak adalah keterampilan gerak yang berguna dalam berolahraga dan aktivitas rekreasi. Keterampilan adalah merupakan perilaku gerak yang secara khusus berguna dalam kehidupan dan aktivitas rekreasi atau olahraga. Contoh keterampilan fungsional 
adalah keterampilan dasar lokomotor dan keterampilan mengontrol objek. Keterampilan dasar lokomotor meliputi keterampilan berjalan, berguling, merangkak, lari, melompat, berjingkat, sliding, memanjat, mencongklang, dan skiping. Keterampilan mengontrol objek meliputi menendang, melempar, menangkap, memukul, dan memantulkan.

4. Tahap keterampilan gerak

Keterampilan olahraga merupakan keterampilan yang diperoleh melalui latihan yang berulang-ulang dan setelah melalui tahap kematangan CNS. Keterampilan olahraga meliputi keterampilan mendribel, menembak, memukul dengan pemukul, melontarkan bola, bermain ski, tumbling, menjebak, dan menyelam.

Berdasarkan tahapan
perkembangan motorik diatas, pembelajaran permainan kecil hendaknya direncanaan secara sistematis. Pelaksanaan pembelajaran permainan kecil berorientasi pada karakteristik dan kebutuhan gerak mahasiswa luar biasa (Auxter David, Pyfer Jean, Hueting Carol, 2010).

\section{Prinsip Pengembangan Permainan Kecil Bagi Mahasiswa Berkebutuhan Khusus}

Hal penting yang harus diketahui dalam prinsip pengembangan permainan kecil bagi mahasiswa berkubutuhan khusus salah satunya harus melibatkan mahasiswa berkebutuhan khusus dengan fasilitator. Berikut prinsip pengembangan permainan kecil :

1. Menjaga unsur kenyamanan dan keselamatan mahasiswa

Unsur kenyamanan dalam keselamatan bagi mahasiswa sebagai pertimbangan mutlak bagi fasilitator dalam tahap penyusunan permainan kecil. Pada saat bergerak atau bermain mahasiswa harus dalam situasi dan kondisi yang tidak membahayakan dirinya untuk mengoptimalkan kegiatan fisik mahasiswa.

2. Sesuai karakteristik mahasiswa

Pada saat mendesain dan mengembangkan permainan, fasilitator harus secara baik memperhatikan dan mempertimbangkan karakteristik mahasiswa. Karakteristik mahasiswa mempengaruhi tingkat partisipasinya dalam permainanan serta meminimalisir cidera otot pada mahasiswa. Karakteristik mahasiswa dalam suatu komunitas sangat bervariatif antara satu dengan yang lainnya.

3. Pemberdayaan kebudayaan secara optimal

Salah satu prinsip yang dituangkan dalam pengembangan permainan kecil adalah pemberdayaan kebudayaan secara optimal. Fasilitator hendaknya mengakomodir kebudayaan setempat dalam bentuk permainan yang dimodifikasi untuk kepentingan pembelajaran.

4. Mobilisasi kegiatan fisik yang tinggi

Prinsip dan esensi dalam pertumbuhan dan perkembangan mahasiswa adalah dengan adanya keterlibatan unsur fisik dan gerak.

5. Peraturan yang praktis, dinamis, dan bermakna

Salah satu karakteristik permainan kecil adalah peraturan permainan yang tidak kaku, monoton, dan mutlak. Artinya peraturan permainan seyogianya dimanfaatkan untuk kepentingan yang lebih menekankan pada perkembangan kognitif, afektif, dan psikomotorik.

6. Media pendukung yang mudah dijangkau Media yang digunakan dalam permainan hendaknya menggunakan media yang mudah didapat, selain murah dalam pembiayaan juga tersedia disekitar lingkungan, selain itu harus mengandung unsur magis/punya daya tarik.

\section{Aspek Strategis Pengembangan Pembelajaran Permainan Kecil \\ Aspek strategi pembelajaran} permainan kecil berperan penting pada pendekatan pembelajaran yang sesuai dengan tingkat karakteristik dan kebutuhan peserta didik. Berdasarkan kebutuhan peserta didik maka desain pembelajaran permainan kecil dilakukan dalam bentuk modifikasi. Bentuk modifikasi pembelajaran permainan kecil dapat dilakukan melalui 
modifikasi alat dan vasilitas, modifikasi peraturan permainan (Hayudi, 2020), modifikasi pendekatan pembelajaran, modifikasi keterampilan bermain.

1. Modifikasi Alat dan Vasilitas

Modifikasi alat yang dimaksud disesuaikan dengan kebutuhan, tentunya kebutuhan mahasiswa tuna netra lebih banyak menggunakan pendengaran, olehnya itu alat yang gunakan harus mudah dikenali berupa alat yang menimbulkan bunyi. Sedangkan vasilitas dalam pembelajaran permainan kecil dapat dilakukan melalui modifikasi lapangan bermain sesuai dengan banyaknya mahasiswa dan tingkat kerumitan permainan.

2. Modifikasi Peraturan Permainan Modifikasi peraturan dalam pembelajaran permainan kecil penting untuk dilakukan berdasarkan banyaknya mahasiswa, ketersedian alat dan vasilitas pembelajaran, serta tingkat kerumitan permainan. Peraturan yang dimodifikasi hendaknya mengakomodir kebutuhan mahasiswa dan bersifat menjaga keselamatan dan kenyamanan mahasiswa.

3. Modifikasi Pendekatan Pembelajaran Modifikasi pendekatan pembelajaran dalam permainan kecil hendaknya berorientasi pada kebutuhan dan kemampuan mahasiswa, ini disebabkan kemampuan mahasiswa sangat beragam olehnya itu pendekatan pembelajaran yang dipilih harus menggunakan berbagai metode sebagai upaya menciptakan pembelajaran yang optimal.

4. Modifikasi Keterampilan Bermain Modifikasi keterampilan bermain dilakukan dalam upaya agar mahasiswa tidak mengalami kebosanan dalam pembelajaran. Modifikasi permainan dalam hal ini adalah tingkat kesulitan materi dari yang paling rendah ke yang paling tinggi atau bisa juga menggabungkan berbagai tingkat keterampilan permainan kecil.

\section{Implementasi Pembelajaran Permainan Kecil Untuk Mahasiswa Berkebutuhan Khusus}

Pentingnya mahasiswa berkebutuhan khusus untuk mengembangkan keterampilannya dalam suatu olahraga (permainan kecil) dengan tujuan untuk menimbulkan antusias dan motivasi, mengembangkan hubungan dengan temantemannya sehingga meningkatkan rasa percaya dan keyakinan diri, serta terlibat aktif dalam aktivitas yang menyenangkan.

Dengan keterlibatan secara aktif dalam pembelajaran permainan kecil berdampak pada kompetensi yang dicapai.

Adapun kompetensi yang akan dicapai sebagai berikut:

1. Waktu Reaksi

Karakteristik mahasiswa tunanetra cenderung menggunakan pendengaran untuk beraktifitas, sehingga dalam proses pembelajaran materi permainan kecil yang dapat diberikan berupa permainan yang dapat mengembangkan pendengaran. Contoh aktivitas permainan yang dapat mengembangkan keterampilan mendengar yaitu permainan bagian tubuh (kerucut), permainan lari melingkar, permainan menyentuh bagian tubuh dan permainan bintang dan garis. Pada permainan diatas keterampilan yang dikembangkan adalah pengambilan keputusan dan komponen kebugaran yang diperlukan adalah waktu reaksi.

2. Keterampilan Bergerak

Kelemahan mahasiswa tunanetra maupun mahasiswa pada umumnya adalah rendahnya aktivitas motorik, sehingga desain pembelajaran yang dapat kembangkan adalah menstimulus mahasiswa agar mau bergerak melalui permainan. Adapun permainan yang dapat dikembangkan adalah tepuk ambil, permainan linda, lempar sasaran, dan permainan dribel bola. Keterampilan yang dikembangkan adalah kemampuan lari, kemampuan mongoper dan menerima bola, serta kemampuan dribel bola. Sedangkan komponen kebugaran yang kembangkan adalah keseimbangan, kecepatan, waktu reaksi, dan daya tahan. 
Jurnal Kejaora: Jurnal Kesehatan Jasmani dan Olah Raga

ISSN: 2541-5042 (Online)

ISSN: 2503-2976 (Print)

Volume 5 Nomor 2, Edisi November 2020

3. Keterampilan Berkoordinasi

Keterampilan berkoordinasi

merupakan keterampilan dalam berkerjasama dalam sebuah tim untuk mencapai suatu tujuan. Contoh aktivitas permainan kecil yang bisa diberikan kepada mahasiswa tunanetra adalah permainan bola gotong, permainan benteng, dan shoting berpasangan. Pada permainan ini keterampilan yang dikembangkan adalah lari, menggulingkan bola, dan keterampilan menangkap,sedangkan komponen kebugaran yang kembangkan adalah ketangkasan, keseimbngan, koordinasi, daya tahan, kerjasama dan kecepatan.

\section{METODE}

Penelitian ini merupakan penelitian pengembangan (Research and Development). Penelitian pengembangan adalah adalah metode penelitian yang digunakan untuk menghasilkan produk tertentu, dan menguji keefektifan produk tersebut (metode penelitian kuantitatif, kualitatif,dan R\&D, 2016).

Pada penelitian ini dilakukan pada mahasiswa UNIMUDA Sorong dengan jumlah subjek sebanyak 15 orang dan uji coba produk dilaksmahasiswaan di SLB Kota Sorong dengan jumlah subjek 20 orang. Prosedur penelitian yang digunakan adalah sebagai berikut (1) Research and Information Collection, yaitu peneliti melakukan kajian awal menganalisis kebutuhan, melakukan pengumpulan informasi lebih lanjut dengan melakukan studi pendahuluan baik dengan cara studi pustaka maupun wawancara langsung dengan dosen pengampu mata kuliah. (2) Planning, pada tahap ini menetapkan rancangan model untuk memecahkan masalah yang telah ditemukan pada tahap awal. Hal yang direncmahasiswaan antara lain: menetapkan model belajar, merumuskan tujuan secara bertahap, mengidentifikasi kegiatan-kegiatan yang dilakukan pada tahap penelitian. (3) Develop Preliminary form of product, tahap ini mulai menyusun perangkat yang diperlukan, produk awal model berupa draf awal penerapan model belajar dan instrumen alat pengumpulan data seperti lembar observasi,

pedoman wawancara yang diperlukan untuk mengumpulkan semua informasi. Proses penelitian pada tahap ini juga dilakukannya validasi rancangan model belajar dengan menggunakan permainan kecil oleh expert judgment. (4), sebelum dilakukan ujicoba harus melakukan tahapan validasi desain terhadap model awal pembelajaran dan memeriksa isi instrumen secara sistematis serta mengevaluasi relevansi dengan variabel yang ditentukan. Hal ini dilakukan untuk mengetahui sejauh mana instrumen yang digunakan dalam penelitian telah mencerminkan keseluruhan aspek yang diukur. (5) Main Product revision, expert judgment menilai dan memberi masukan terhadap produk awal, proses ini dilakukan sampai menunjukkan bahwa produk awal tersebut valid dan layak di ujicobakan. (6) Main filed testing, pelaksanaan uji coba produk di mahasiswa Unimuda Sorong, kemudian di lakukan observasi expert judgment. (7) Operational product revision, revisi produk yang dilakukan dari hasil uji coba produk. (8) Operational field testing, uji produk di laksmahasiswaan pada SLB Kota Sorong. (9) Final Product revision, proses revisi produk dilakukan untuk mendapat masukan dari expert judgment agar menghasilkan produk final, langkah ini merupakan penyempurnaan produk yang dikembangkan agar produk akhir lebih akurat. Instrumen pengumpulan data pada penelitian ini menggunakan 2 (dua) pendekatan yaitu:

1. Wawancara, yaitu teknik pengumpulan data apabila peneliti ingin melakukan studi pendahuluan untuk menemukan permasalahan yang harus diteliti, dan juga apabila peneliti ingin mengetahui hal-hal dari responden yang lebih mendalam dan jumlah respondennya sedikit/kecil (Sugiyono, 2016). Dalam hal ini peneliti sudah membuat daftar pertanyaan yang mendukung data penelitian.

2. Kuesioner, yaitu teknik pengumpulan data yang dilakukan dengan cara memberi seperangkat pertanyaan atau pernyataan tertulis kepada responden untuk dijawabnya. Dalam hal ini peneliti sudah membuat daftar pernyataan dengan 
kategori sangat setuju (4), setuju (3), tidak setuju (2), dan sangat tidak setuju (1).

Teknik analisis data uji coba menggunakan teknik analisi data deskriptif persentase (\%). Rumus: $\mathrm{P}-\frac{n}{N} \times 100 \%$ $\mathrm{P} \quad=$ Persentase hasil

$$
\begin{array}{ll}
\mathrm{N} & =\text { Jumlah jawaban skor } \\
\mathrm{N} & =\text { Jumlah jawaban maksimal } \\
100 \% & =\text { Konstanta }
\end{array}
$$

Untuk menentukan kesimpulan yang telah tercapai maka ditetapkan kriteria seperti pada tabel berikut

Tabel 1. Presentase Keberhasilan

\begin{tabular}{cc}
\hline Persentase & Keterangan \\
\hline $\mathbf{8 0} \%-\mathbf{1 0 0} \%$ & Valid/digunakan \\
\hline $\mathbf{6 0 \% - 7 9 \%}$ & Cukup Valid/digunakan \\
\hline $\mathbf{5 0 \% - 5 9 \%}$ & Kurang Valid/diganti \\
\hline$<\mathbf{5 0} \%$ & Tidak Valid/diganti \\
\hline \multicolumn{2}{c}{ Sumber: ( Ali Maksum, 2012) }
\end{tabular}

\section{HASIL DAN PEMBAHASAN}

Dalam penelitian ini produk yang dihasilkan berupa permainan kecil yaitu:

\section{Permainan Bagian Tubuh (Kerucut)}

Hasil penilaian expert judgment data kuesioner dengan analisis deskriptif persentase terhadap permainan bagian tubuh (kerucut) dimasukkan dalam rumus,

Tabel 1. Expert Judgment Permainan Bagian Tubuh (Kerucut)

\begin{tabular}{cccccccccc}
\hline \multirow{2}{*}{ Tahap } & \multirow{2}{*}{ Expert } & 1 & 2 & 3 & 4 & 5 & Jumlah & \multirow{2}{*}{$\%$} & \multirow{2}{*}{ Keterangan } \\
\hline \multirow{3}{*}{ Draft Awal } & Akademisi & 4 & 3 & 4 & 3 & 3 & 17 & 85 & Valid \\
& Praktisi 1 & 3 & 4 & 3 & 3 & 3 & 16 & 80 & Valid \\
& Praktisi 2 & 3 & 4 & 3 & 4 & 3 & 17 & 85 & Valid \\
\multirow{5}{*}{ Skala Kecil } & Akademisi & 3 & 4 & 4 & 4 & 3 & 18 & 90 & Valid \\
& Praktisi 1 & 4 & 3 & 4 & 4 & 4 & 19 & 95 & Valid \\
& Praktisi 2 & 3 & 3 & 4 & 4 & 4 & 18 & 90 & Valid \\
& Akademisi & 4 & 4 & 4 & 4 & 4 & 20 & 100 & Valid \\
& Praktisi 1 & 4 & 4 & 4 & 3 & 4 & 19 & 95 & Valid \\
& Praktisi 2 & 4 & 4 & 4 & 4 & 4 & 20 & 100 & Valid \\
\hline
\end{tabular}

Berdasarkan hasil penilaian expert judgmen terhadap model permainan bagian tubuh (kerucut) dinyatakan valid.

2. Permainan Tepuk Ambil

Hasil penilaian expert judgment data kuesioner dengan analisis deskriptif persentase terhadap permainan tepuk ambil dimasukkan dalam rumus,

\begin{tabular}{|c|c|c|c|c|c|c|c|c|c|}
\hline \multirow[b]{2}{*}{ Tahap } & \multirow[b]{2}{*}{ Expert } & \multicolumn{5}{|c|}{ Nilai Kuesioner } & \multirow[b]{2}{*}{ Jumlah } & \multirow{2}{*}{$\%$} & \multirow{2}{*}{ Keterangan } \\
\hline & & 1 & 2 & 3 & 4 & 5 & & & \\
\hline \multirow{3}{*}{ Draft awal } & Akademisi & 3 & 3 & 3 & 4 & 4 & 17 & 85 & Valid \\
\hline & Praktisi 1 & 4 & 3 & 4 & 3 & 3 & 17 & 85 & Valid \\
\hline & Praktisi 2 & 3 & 3 & 3 & 3 & 4 & 16 & 80 & Valid \\
\hline \multirow{3}{*}{ Skala Kecil } & Akademisi & 3 & 3 & 4 & 4 & 4 & 18 & 90 & Valid \\
\hline & Praktisi 1 & 4 & 3 & 3 & 4 & 3 & 17 & 85 & Valid \\
\hline & Praktisi 2 & 4 & 4 & 4 & 3 & 4 & 19 & 95 & Valid \\
\hline \multirow{3}{*}{ Skala besar } & Akademisi & 4 & 4 & 4 & 4 & 4 & 20 & 100 & Valid \\
\hline & Praktisi 1 & 4 & 4 & 4 & 4 & 4 & 20 & 100 & Valid \\
\hline & Praktisi 2 & 4 & 4 & 4 & 4 & 4 & 20 & 100 & Valid \\
\hline
\end{tabular}

$$
\text { Nilai }=\frac{\text { jumlah } \text { skor angket }}{\text { jumlah pertanyaan angket }} \times 100 \%
$$

Tabel 3. Expert Judgment Permainan Tepuk Ambil 
Jurnal Kejaora: Jurnal Kesehatan Jasmani dan Olah Raga

ISSN: 2541-5042 (Online)

ISSN: 2503-2976 (Print)

Volume 5 Nomor 2, Edisi November 2020

Berdasarkan hasil penilaian expert judgmen terhadap model permainan tepuk ambil dinyatakan valid.

\section{Permainan Bola Gotong}

Hasil penilaian expert judgment data kuesioner dengan analisis deskriptif

persentase terhadap permainan bola gotong dimasukkan dalam rumus,

Nilai $=\frac{\text { jumlah } \text { skor angket }}{\text { jumlah pertanyaan angket }} \times 100 \%$

Tabel 3. Expert Judgment Permainan Bola Gotong

\begin{tabular}{|c|c|c|c|c|c|c|c|c|c|}
\hline \multirow{2}{*}{ Tahap } & \multirow{2}{*}{ Expert } & \multicolumn{5}{|c|}{ Nilai Kuesioner } & \multirow{2}{*}{ Jumlah } & \multirow[b]{2}{*}{$\%$} & \multirow{2}{*}{ Keterangan } \\
\hline & & 1 & 2 & 3 & 4 & 5 & & & \\
\hline \multirow{3}{*}{ Draft awal } & Akademisi & 3 & 3 & 3 & 3 & 4 & 16 & 80 & Valid \\
\hline & Praktisi 1 & 3 & 3 & 3 & 4 & 4 & 17 & 85 & Valid \\
\hline & Praktisi 2 & 4 & 3 & 4 & 4 & 3 & 18 & 90 & Valid \\
\hline \multirow{3}{*}{ Skala Kecil } & Akademisi & 3 & 4 & 3 & 3 & 4 & 17 & 85 & Valid \\
\hline & Praktisi 1 & 4 & 4 & 4 & 3 & 3 & 18 & 90 & Valid \\
\hline & Praktisi 2 & 4 & 3 & 4 & 4 & 4 & 19 & 95 & Valid \\
\hline \multirow{3}{*}{ Skala besar } & Akademisi & 4 & 4 & 4 & 4 & 4 & 20 & 100 & Valid \\
\hline & Praktisi 1 & 4 & 4 & 4 & 4 & 4 & 20 & 100 & Valid \\
\hline & Praktisi 2 & 4 & 4 & 4 & 4 & 4 & 20 & 100 & Valid \\
\hline
\end{tabular}

Berdasarkan hasil penilaian expert judgmen terhadap model permainan bola gotong dinyatakan valid.

\section{KESIMPULAN}

Pada dasarnya mahasiswa berkebutuhan khusus memerlukan dukungan maksimal dari lingkungan sekitarnya, salah satu bentuk dukungan yang nyata bagi mahasiswa berkebutuhan khusus yaitu melalui modifikasi permainan kecil dalam mata kuliah pendidikan jasmani. Olehnya itu pembelajaran permainan kecil harus didesain secara variatif untuk mengembangkan motivasi, kepercayaan diri dan keterampilan motorik mahasiswa.

Simpulan dalam penelitian ini adalah menghasilkan produk berupa model modifikasi permainan kecil yang terdiri atas: 1) permainan bagian tubuh (kerucut), 2) permainan tepuk ambil, 3) permainan bola gotong. Model-model tersebut telah dinilai oleh expert judgment dan mendapatkan simpulan bahwa model tersebut dinyatakan valid dan layak untuk digunakan.

Hal-hal yang belum termuat pada penelitian ini yaitu peneliti hanya difokuskan pada mahasiswa yang mengalami hambatan dengan kategori tunanetra ringan, sehingga kedepan bagi peneliti selanjutnya adalah agar meneliti mahasiswa atau pelajar yang mengalami hambatan tunanetra berat (tidak bisa melihat sama sekali).

\section{DAFTAR PUSTAKA}

Abduljabar, B. (2011). Pengertian Pendidikan Jasmani. IImu Pendidikan.

Abdullah, N. (2012). Bagaimana mengajar mahasiswa tunanetra (di sekolah inklusi). Magistra.

Ali Maksum. (2012). Pengumpulan data. Jurnal Metode Pengumpulan Data.

April, A. E. E. (2015). Inovasi Media Pembelajaran. Artikel E-Buletin.

Bangun, S. Y. (2016). Peran Pendidikan Jasmani Dan Olahraga Pada Lembaga Pendidikandi Indonesia. Publikasi Pendidikan. https://doi.org/10.26858/publikan.v6i3 .2270

Hakim, A. R. (2017). Memuliakan Mahasiswa Berkebutuhan Khusus Melalui Pendidikan Jasmani Adaptif. Jurnal IImiah Penjas.

Hayudi. (2020). Peningkatkan Kemampuan Passing Bawah dengan Menggunakan Metode Bervariasi Permainan Bola Voli pada Mahasiswa Pendidikan Jasmani Universitas Pendidikan Muhammadiyah Sorong. Jurnal Pendidikan, 8(1), 71-77. https://unimuda.e-

journal.id/jurnalpendidikan/article/view /387/348

Khoiroh, A., \& Paramita, P. P. (2014). Peran Dukungan Sosial terhadap Pembentukan Self Esteem yang 
Jurnal Kejaora: Jurnal Kesehatan Jasmani dan Olah Raga

ISSN: 2541-5042 (Online)

ISSN: 2503-2976 (Print)

Volume 5 Nomor 2, Edisi November 2020

Tinggi pada Remaja Tunanetra di Sekolah Khusus. Jurnal Psikologi Industri Dan Organisasi.

Kurniawan, A., \& Hayudi, H. (2018). Pengembangan Buku Ajar Strategi Pembelajaran Pendidikan Jasmani Melalui Olahraga Permainan Kecil. Jurnal Kejaora (Kesehatan Jasmani Dan Olahraga). https://doi.org/10.36526/kejaora.v3i2. 210

Muharomah, S. (2016). PENGGUNAAN BAHASA PADA MAHASISWA TUNANETRA: (Pengamatan terhadap Mahasiswa Tunanetra melalui Proses Penalaran dalam Kegiatan Tari di Panti Sosial Bina Netra Cahaya Bathin). Deiksis.

Ratnasari, M. N. I. (2015). Penerapan Model Pembelajaran Langsung Untuk Meningkatkan Orientasi dan Mobilitas Mahasiswa Tunanetra Merrynda. Jurnal Pendidikan Khusus Penerapanmodel.

Setianingsih, E. S. (2018). Implementasi Pendidikian Inklusi: Manajemen Tenaga Kependidikan (GPK). Malih Peddas (Majalah IImiah Pendidikan Dasar).

https://doi.org/10.26877/malihpeddas. v7i2.1808

Siti Zubaidah. (2016). Keterampilan Abad Ke21: Keterampilan Yang Diajarkan Melalui Pembelajaran. Seminar Nasional Pendidikan. https://doi.org/10.1021/acs.langmuir.6 b02842

Metode Penelitian Kuantitatif, Kualitatif,dan R\&D, Alfabeta, CV. (2016).

Utama, A. M. B. (2011). pembentukan karakter mahasiswa melalui aktivitas bermain dalam pendidikan jasmani. Pendidikan Jasmani Indonesia.

Wardah, E. Y. (2019). Peranan Guru Pembimbing Khusus Lulusan NonPendidikan Luar Biasa (Plb) Terhadap Pelayanan Mahasiswa Berkebutuhan Khusus Di Sekolah Inklusi Kabupaten Lumajang. JPI (Jurnal Pendidikan Inklusi).

https://doi.org/10.26740/inklusi.v2n2.p 93-108 